\title{
THE GLOBAL GIG ECONOMY: TOWARDS A PLANETARY LABOUR MARKET?
}

\author{
Mark Graham ${ }^{1}$ \\ Mohammad Amir Anwar, ${ }^{1,2}$ \\ ${ }^{1}$ Oxford Internet Institute, University of Oxford \\ ${ }^{1,2}$ School of Tourism and Hospitality, University of Johannesburg \\ Mark.graham@oii.ox.ac.uk \\ mohammad.anwar@oii.ox.ac.uk
}

\section{This is an Open Access Article}

This paper is published by First Monday.

Suggested citation: Graham, M and Anwar, M. A. (2019) The Global Gig Economy: Towards a Planetary Labour Market, First Monday, Vol. 24, No. 4.

\section{Acknowledgments}

The authors would like thank David Sutcliffe, Jamie Woodcock, and Alex Wood for their extensive feedback on earlier drafts and anonymous referees for their comments. We are grateful to the European Research (ERC Grant Agreement n. 335716) and the ESRC (ES/S00081X/1) for funding our research on digital work. 


\section{Introduction}

"The more production comes to rest on exchange value, hence on exchange, the more important do the physical conditions of exchange - the means of communication and transport - become for the costs of circulation. Capital by its nature drives beyond every spatial barrier. Thus, the creation of the physical conditions of exchange - of the means of communication and transport - the annihilation of space by time - becomes an extraordinary necessity for it." (Marx, 1973, p. 524).

Our world of work is seemingly in crisis. Everywhere we look there are bold proclamations about the ways that technologies are expected to destroy, move, and deskill jobs ${ }^{1}$. This article seeks to begin from these visions of a rapidly changing world of work, and argue that we are witnessing the emergence of a 'planetary labour market' in digital work. By changing the geography of work, a planetary labour market introduces some serious concerns for the livelihoods and structural power of workers. Now more than ever is David Harvey's famous maxim about the relative power of capital over labour relevant. ${ }^{2}$ This article points to a need for a reinvigorated programme of research and activism to tackle this fact.

Today's online outsourcing platforms host all manner of jobs: ranging from click-work to the training of machine learning systems to transcription to live personal assistance and everything in between. These online outsourcing platforms, by becoming key intermediaries in the labour process of outsourced work (Casilli and Posada, 2019), potentially augur a radical shift in the scales at which capital can interact with labour ${ }^{3}$. Upwork, a platform with 12 million registered workers, explains the advantages to clients with the following text on

\footnotetext{
${ }^{1}$ In addition to numerous models that have been created to predict home many jobs Artificial Intelligence will destroy, it is estimated that up to one third of all jobs in the United States are offshorable (Peck 2017).

2 As David Harvey (1991, p. 19) noted, "labour power has to go home every night". Capital therefore is always able to take advantage of its relative mobility compared to labour.

3 Large platforms began to emerge after 2008 as a new business model that controlled information in bottlenecks in between digitally-mediated economic, social, and political activities. According to Srnicek (2016: 48) "Platforms, in sum, are a new type of firm; they are characterised by providing the infrastructure to intermediate between different user groups, by displaying monopoly tendencies driven by network effects, by employing cross-subsidisation to draw in different user groups, and by having a designed core architecture that governs the interaction possibilities."
} 
their website: "online work can happen wherever there's a reliable Internet connection an office, home, café, or rooftop. This also means you can choose who you work with, among a larger pool of people from around the globe." One of the world's largest online outsourcing platforms, Freelancer.com, display their logo and the statement " 25 million lives changed" over a map of the planet (noting that their location is 'everywhere'). Similarly, Appen, a platform company with workers who train machine learning systems in 180 countries, explicitly advertise their 'global crowd' of workers on their website. The increasing digitisation of work and recent advancements in automation and communication technologies don't just augment the labour process with digital data, digital processes, and machines; they also embed it in stretched-out networks of production: with tasks quickly passed in complex assemblages from person to person, person to machine, and machine to machine.

While these arguments are better covered elsewhere, this article instead seeks to build on them to make an argument about the spatial implications of these changes.

We will to use online outsourcing/platform work as a key case of 'digital work' in the rest of the article. Work, in other words, done over the wires and mediated through a platform; work that does not necessarily require proximity between the worker, the work itself, and the site of the immediate delivery of the work. The relative lack of fixed organisational infrastructure needed for the online outsourcing sector means that it can be characterised by a broad geographic spread. Unlike traditional forms of employment, companies that outsource digital work, and platforms that mediate those relationships, tend to avoid any formal employment of workers and don't need to share proximity to workers. Jobs are instead listed on digital platforms that allow workers to bid for them. These jobs might take anything from minutes (e.g. click work or image tagging) to months (large writing tasks or 
web design) to complete. According to Heeks (2017), there are about 70 million registered platform workers globally, in the market for work that the World Bank estimates will grow to $\$ 15-\$ 20$ billion by 2020 (Kuek et al., 2015). The economist Guy Standing (2016), meanwhile, predicts that by 2025, platforms will mediate one third of all labour transactions. The scale and scope that some of these platforms can achieve is in part driven by the development of development of planetary-scale infrastructures of computation (Bratton 2016).

Because of the rapid rise of digital work around the world, we ask in this article whether we are seeing the emergence of a 'planetary labour market' in digital work. To answer this question, we outline the scalar and spatial changes that have been occurring in labour markets, review their implications for the balance of power between labour and capital, and advance some possible responses to ensure that we do not get trapped in a global race to the bottom in which there are constant downwards pressures on wages and working conditions.

The argument that we make here is largely conceptual. However, we illustrate our argument with examples from a five-year (2014-2018) study of digital work in some of the world's economic margins. We conducted semi-structured interviews with 65 online platform workers in South Africa, Kenya, Nigeria, Ghana and Uganda, recruited from one of the world's biggest online labour platforms, Upwork. We sought maximum diversity in our sample, and our respondents were characterised by a range of different attributes, such as number of hours worked on the platform, different types of work activities, and income earned. Most workers in our sample had multiple accounts on various platforms such as Freelancer.com, Fiverr.com and Peopleperhour.com. We also recruited Upwork workers through social media (Facebook and LinkedIn) and snowballing. The primary sampling goal 
was to ensure a diversity of worker experiences. As such, this paper presents selected cases that indicate the existence of activities, issues, and concerns, rather than a representative view. Through the interviews we sought to understand the socio-economic background of workers, the nature and types of work done by these workers, career prospects, livelihood challenges, income, worker-worker and worker-client interactions, strategies to win bids, to stay competitive, to demand higher wages and negotiate working hours, and actions to avoid the various risks inherent to platform work. All the worker names have been changed.

\section{Moving Beyond Local Labour Markets}

To describe what is meant by a planetary labour market, it is first useful to describe what labour markets are. A nineteenth-century hiring fair, such as the one described by Thomas Hardy in Far From the Madding Crowd, is used by Fevre (1992), in his book about the sociology of labour markets, as a way of illustrating an abstract definition of labour markets through five key distinct processes. These are: informing employers (employers learning about availability and skills of workers), informing workers (workers learning about jobs), screening workers (employers obtaining enough information about workers to decide if they could be hired for a job), screening employers (workers learning about their employers), and offers to buy or sell labour (the actual negotiations and pitches made by workers and employers). Labour markets, in other words, are a way of describing a convergence of workers and employers in specific places and times. While scholars as far back as Karl Marx posited that this convergence in competitive labour markets is a fundamental characteristic of capitalist society, various planned economies in the late $20^{\text {th }}$ century likewise relied on the concept of a labour market to govern the management and distribution of the labour force (Brown 1970). 
In Hardy's hiring fair, the spatial and temporal co-presence of agricultural workers and employers allowed the five above-mentioned processes to converge. However, while copresence has traditionally been a necessary condition for most of these conditions, it has not been a sufficient one. Kalleberg and Sorenson $(1979,351)$ define labour markets as "the arenas in which workers exchange their labor power in return for wages, status, and other job rewards. The concept, therefore, refers broadly to the institutions and practices that govern the purchase, sale, and pricing of labor services. These structures include the means by which workers are distributed among jobs and the rules that govern employment, mobility, the acquisition of skills and training, and the distribution of wages and other rewards obtained contingent upon participation in the economic system." But, ultimately, those institutions and practices still require some level of space-time convergence between employers and workers.

It is important here to distinguish between the way that labour markets have been conceived in orthodox classical economics, and their actual characteristics. Orthodox conceptions put forward a perfectly competitive market that can provide both firms (buyers) and workers (sellers) with perfect information. Wages are set by the relationship between supply and demand, and "workers can move freely in response to changes in supply and demand in different parts of the market." (Kalleberg and Sorensen, 1979, p. 354). Kalleberg and Sorensen (1979) give examples of such markets as the migrant labour market in California, and the 1970s labour market in Afghanistan. In both cases, wages were relatively uniform and institutional forces only had a small influence. In practice, it is rare for labour markets to fit these sorts of perfect property, instead, labour markets function in imperfect and uneven ways. Workers comprise different classes, genders, races, nationalities, and other groups that can get segmented into different 
functions in labour markets. These markets are further built on, and performed through imperfect information, irrational social behaviours, politics, institutional arrangements and practices, customs, and prejudices. As Peck $(1996$, p. 5) has argued, labour markets are "socially constructed and politically mediated" arenas, "structured by institutional forces and power relations". Thus, we get segmented labour markets functioning at multiple scales and spaces to produce variegated outcomes for workers (Craig et al., 1982). In these segmented or split markets, workers have little opportunity to cross into other groups and are thus constrained to a limited set of outcomes: with factors like gender or race influencing segmentation (with, for instance, women earning lower wages than men) (Bonacich, 1972; Reich et al., 1973). ${ }^{4}$

The takeaway point here is that labour markets function in complex, imperfect, exclusionary ways. When speaking about a physical meeting place, like a hiring fair, the very concept serves as a multi-scalar abstraction. We use the idea of national or regional labour markets not to imply that everyone in those nations or regions have equal opportunities to read or access the market; but rather as a way of indicating that there are distinct economic, social, and political enablers and constraints that put rough, porous, but still real geographic boundaries around Fevre's five processes. This is not to say that workers are not enrolled into global-scale associations and production networks. Indeed, workers in many economic sectors have been for centuries (Hunt, 2010). But, as Fevre (1992: p. 14) notes, "Labour markets need have neither a fixed time nor a fixed place, but they must have some sort of 
time and place otherwise how could people use them? If they do not know when and where, workers cannot find jobs and employers cannot hire workers."

Much of this discussion assumes a located place of work - a farm, factory, or office that a worker needs to be physically present in, in order to perform their duties. But, as the nature of work changes, so too must our conceptions of the boundedness of labour markets. Here it is useful to draw on the concept borrowed from geography of a relational understanding of space (Massey, 2005). Rather than only thinking of space as a canvas, it is rather something that can also emerge from social relations (Hudson, 2001). This vision of space as relational and emergent, rather than pre-existing, is useful because it offers a productive way of understanding the impact of digital technologies on labour markets. Stephen Graham (1998, p.174), in an influential piece on the intersections between technology and space, builds a relational understanding, noting that "such a perspective reveals how new technologies become enrolled into complex, contingent and subtle blendings of human actors and technical artefacts, to form actor-networks." He continues: "new information technologies, in short, actually resonate with, and are bound up in the active construction of space and place, rather than making it somehow redundant".

If we apply these sorts of understandings to the contexts of work, the boundedness of earlier visions of labour markets evaporate. Building on an actor-network understanding of work as constituted through a broad range of associations with objects, Jones (2008, p. 12) further argues that "working practices, the experience of work, the nature of workplaces and the power relations in which people's working lives are entangled require a theoretical understanding of global-scale interrelationships if they are to be properly understood." Describing how work is increasingly performed through global networks of human and nonhuman objects, he adds: "Contemporary work is becoming less constituted through 
localised, physically-proximate relations and increasingly constituted through distanciated relations. These multiple spatial associations increasingly extend to the planetary scale" (p. 14). This starting point - moving beyond an understanding of work as inherently local allows Jones (2008, p. 15) to then build his 'global work' thesis:

Rather than understanding work as a practice undertaken by social actors located in discrete material spaces and framed in a linear chronology, work is reconceptualised as a complex set of spatialised practices involving humans and non-humans..., and which is constituted in relational space with a disjunctive, non-linear chronology... This is 'global' work because this reconfigured concept captures the qualitative degree to which all work practices are constituted through distanciated...socio-material relations.

As the places of work move beyond single locations, this offers us a pathway for thinking through the impacts of globalisation on workers.

\section{Towards a Planetary Labour Market}

Although the 'global work' thesis is useful for providing a framework that allows us to carefully think through the impacts of globalisation on workers and the ways that the places of work move beyond single locations, in the rest of this article we will argue that it is important to think about the relationships between employers and workers as more than simply distanciated social relations. Using the idea of a 'planetary labour market' allows us to show that not just work can be highly (globally) connected, but rather temporary states of co-presence between workers and employers that can be brought into being. 
Like Jones (2008), we build our understanding of a planetary labour market on a relational understanding of space. Specifically, we draw from Doreen Massey (1993, p. 61) who argued that:

Different social groups and different individuals are placed in very distinct ways in relation to ... flows and interconnections. This point concerns not merely the issue of who moves and who doesn't, although that is an important element of it; it is also about power in relation to the flows and the movement. Different social groups have distinct relationships to this anyway-differentiated mobility: some are more in charge of it than others; some initiate flows and movement, others don't; some are more on the receiving end of it than others; some are effectively imprisoned by it.

As such, the moments of co-presence that will be described below rarely fit either the orthodox idea of labour markets or resemble Hardy's nineteenth century hiring fair. While digital work platforms have enabled the potential coming together of employers and workers on a planetary scale, the labour market for digital work that is developing is characterised by both asymmetrical scalar relationships and uneven spatial ones: with workers and employers having very different possibilities to read and participate in the labour market. In other words, the argument put forward in this article is a planetary labour market is not simply a 'global' extension of Hardy's hiring fair. It facilitates coming-togethers that can transcend the spatial boundaries that constrained the convergence of employers and workers, but remained shaped and characterised by multi-scalar and asymmetrical technological, political, social, cultural and institutional factors. 
This section returns to Fevre's (1992) five characteristics of labour markets ('employers learn about workers, workers learn about jobs, employers obtain information about workers, workers obtain information about employers, and offers to buy and sell labour transpire') and asks how they apply to the planetary labour market brought into being through online outsourcing. Within each of the following sections, we outline a range of concerns that relate to the structural power of labour vis-à-vis that of capital. This strategy is neither intended to imply that these are the only concerns, or that there are not benefits (such as flexibility) to workers at the individual scale.

\section{1) Employers learn about workers}

In the case of online outsourcing, employers (i.e. 'clients') have genuine planetary reach when learning about workers. Employers list requirements needed from their workers on online labour platforms, and workers from around the world then bid on those jobs allowing employers to collect certain information they need about any potential worker. The fact that online outsourcing platforms tend to have a massive oversupply of workers on them (Graham et al., 2017a) means that workers are eager to supply any information that potential employers require. This will typically include location, ratings, reviews, previous clients' feedback, but may also include work history, previous experience, number of hours worked, education, and a host of interpersonal skills. When we compare the ways in which employers learn about workers to the ways that workers learn about jobs, the scalar differences in how workers and employers can read the planetary labour market become apparent.

Figure 1 shows where workers on the world's largest online labour platforms are based. It demonstrates that Upwork and Freelancer's claims to host workers from almost everywhere on the planet are true, and that there are very few countries with a 'no data' label that do 
not at least host at least some workers in online labour platforms. However, it is also obvious that there are distinct patterns to the supply of online labour power with large concentrations of workers in a few countries. Employers can join these platforms to either find workers in specific places (for instance when language skills are needed) or to put a job out to competition from workers that can be located anywhere.

Figure 1: The Availability of Online Workers. Reproduced from Ojanperä et al. (2018).

The Availability of Online Workers
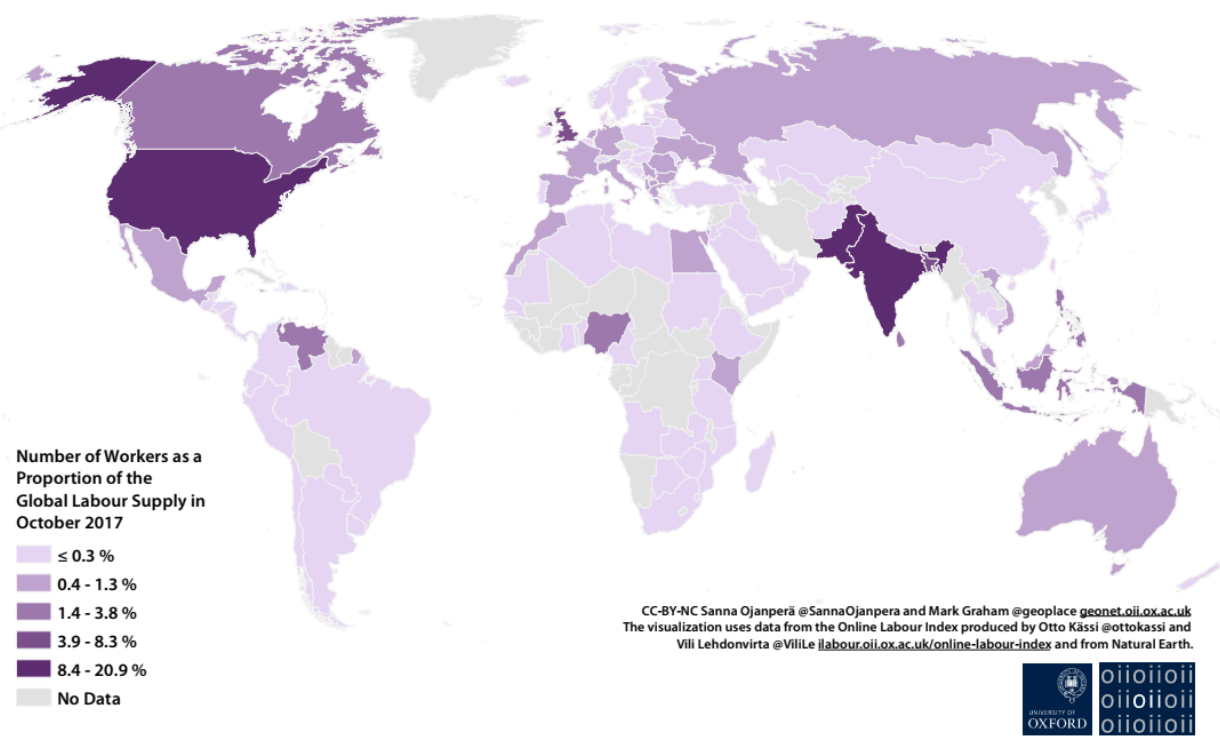

This huge number of people who sign up to look for jobs ends up creating a huge oversupply of labour. In Table 1, we present data collected from Upwork on a single day in October 2018 , to estimate at the potential oversupply of labour on the platform. The table compares the number of people signed up on the platform by country, with the number of workers who have ever earned at least US\$1 or worked at least one hour on the platform. Even with such a low threshold of what constitutes work, we see a massive oversupply in the sample 
of countries in Table 1. Globally, less than seven percent of people who register for jobs are ever able to secure one ${ }^{5}$.

Table 1: Oversupply of labour on Upwork.com. Data for October 24, 2018, collected and analysed by the authors.

\begin{tabular}{|l|l|l|l|l|}
\hline Country & $\begin{array}{l}\text { Potential } \\
\text { Workforce }^{\mathrm{a}}\end{array}$ & $\begin{array}{l}\text { Successful } \\
\text { Workers }^{\mathrm{b}}\end{array}$ & Over-supply & $\begin{array}{l}\text { Over-supply } \\
\text { Percentage (\%) }^{(\%)}\end{array}$ \\
\hline Global & $1,891,648$ & 128,259 & $1,763,389$ & $93.2 \%$ \\
\hline United States & 581,717 & 23,845 & 557,872 & 95.9 \\
\hline India & 249,698 & 22,772 & 226,926 & 90.8 \\
\hline Philippines & 164,757 & 18,869 & 145,888 & 88.5 \\
\hline Pakistan & 66,681 & 6,032 & 60,649 & 90.9 \\
\hline United Kingdom & 56,644 & 2,924 & 53,270 & 94.8 \\
\hline Ukraine & 55,604 & 8,506 & 47,098 & 84.7 \\
\hline Egypt & 35,299 & 1,295 & 34,004 & 96.3 \\
\hline Kenya & 18,508 & 898 & 17,610 & 95.1 \\
\hline Malaysia & 13,385 & 317 & 13,068 & 97.6 \\
\hline South Africa & 12,723 & 593 & 12,130 & 95.3 \\
\hline Nigeria & 8,032 & 297 & 7,735 & 96.3 \\
\hline Vietnam & 7,574 & 669 & 6,905 & 91.1 \\
\hline Ghana & 1,656 & 50 & 1,606 & 96.9 \\
\hline Uganda & 1,176 & 31 & 1,145 & 97.3 \\
\hline
\end{tabular}

a Total searchable worker profiles.

${ }^{b}$ Searchable worker profiles with at least one hour worked and US\$1 earned.

c Potential workforce minus successful workers.

While the geography of online labour is far from equally spread around the world, the relative ubiquity of digital connectivity, and the affordances that digital labour platforms provide, mean that employers can now find new workers on the other side of the world in minutes, as long as workers have relevant ICT tools and internet connectivity. However, for workers, the combination of the global market and the oversupply of labour power (or at least the perception of the oversupply of labour power) is experienced as something that significantly depresses the wages they are able to command (see also Graham et al. 2017b

\footnotetext{
${ }^{5}$ Too much should not be read into the specific oversupply percentages. On one hand, these numbers could be overestimates because it is possible that many people create profiles without having any intention to search for jobs. On the other, it is possible that they are underestimates, because platforms have an interest in keeping pay just above the reserve wage in a variety of industries, there have been time-limited efforts to limit worker sign-ups from some countries.
} 
and Wood et al. 2018b for more on this point). Adele, a data entry worker in South Africa described how this situation played out on the platform Upwork: "You go apply for a job and somebody else will come and apply for less than dollar. Other people are bidding too low and it was people from the Philippines and India. I was angry because they bid too little and...Yet they are happy. Yeah, I was quite pissed off there; I was like no way are they doing this!"

\section{2) Workers learn about jobs}

Workers on online outsourcing platforms naturally have a geographically expanded pool of jobs to bid for, compared with the jobs available in their local labour markets. Most platforms allow workers to bid for jobs from anywhere. However, this differs from a simple state of co-presence for two reasons. First, while workers can learn about task vacancies on platforms, clients often reveal relatively little about themselves. Second, these platforms tend to facilitate vertical communication rather than horizontal communication (between workers), thus limiting the associational power of workers.

On the first point, the ability for workers to learn basic information about the jobs, but relatively little about their bosses is particularly pronounced for workers doing short-term and fixed-price jobs such as document conversion, transcription, and writing jobs. Some longer-term jobs such as web-chat support, digital marketing, and virtual assistants should in theory allow workers to learn more about clients and their businesses over the course of time and therefore build a relationship of trust with them. Yet, even with these longer-term jobs, many workers struggle to get know their clients. A Kenyan Data Entry Worker, Eidi, noted that despite working on a content generation project for over a year, she only knows her line manager who sits in Uganda and has no idea who the main client is, or the owner of 
the project. Some clients don't tell workers in detail what the job actually requires them to do (see Figure 2 , simply advertising "repetitive" work).

Figure 2: Job advert on an online outsourcing platform, revealing little detail of the task being advertised

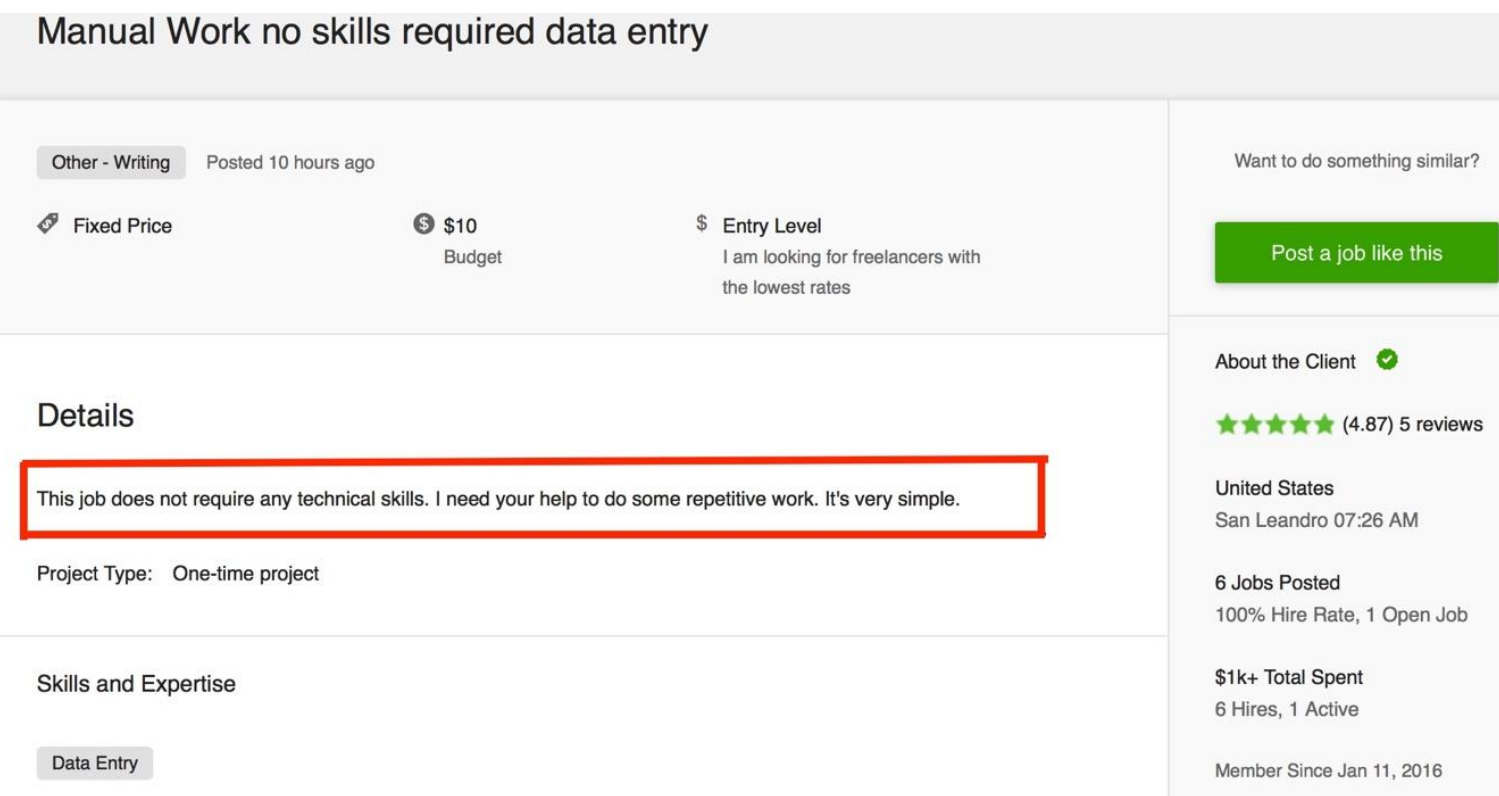

Here it important to remember that the affordances of online outsourcing platforms are designed for workers and clients to connect with one another, rather than for workers to connect with each other. Historically, the inability for workers to have any effective virtual co-presence has severely limited associational power (Wood et al., 2018a). While Fordism enhanced workplace bargaining power (based on the ability of workers to threaten to stop the entire production chains) by uniting workers at the point of production (i.e. physical factories), it decreased marketplace bargaining power (based on the possession of scarce skills and low levels of general unemployment) by bringing a global reserve army of labour under capital's control (Silver, 2003). The point is if by fixing labour in a place often gives it power, it can also be undermined by multiple spatio-temporal fixes created by capital since the crises of the 1970s (1973 oil price crisis, 1973-74 Stock Market crash, the fall of the 
Bretton Woods System) (Harvey, 2011, 2001). Put differently, relocation of production gave new entrant labour forces a sense of class identity and bargaining power at the workplace, but the ease with which production can be relocated meant an undermining of marketplace bargaining power and threats of job losses. The mobility of capital through the reorganisation of production techniques (fragmentation and relocation of production) has tended to weaken the associational power of workers due to the incorporation of a mass of unemployed and unorganised workers who are hard to unionise. Workers lack a sense of collective identity as a working class and a weak state regulatory framework delegitimize trade unions, making it incredibly hard for such organisations to deliver benefits to workers (Silver, 2003).

These trends have continued with the emergence of digital work that can be performed by a global pool of unorganised workers separated by large physical distances, and workers lacking common linguistic and cultural characteristics. The inability for platform workers to have any effective virtual co-presence severely limits their associational power (see also Wood et al., 2018a). This largely relates to the nature of digital work, the technical structure of platforms, the transaction of digital work through the Internet, and a global pool of workers who are fragmented and commoditised.

The demand by clients for work to be completed before a set deadline forces workers to confine themselves to their workplaces (usually their rooms), working long hours with high work intensity to avoid losing wages. Mukondi, in Kenya, was doing internet research for a US-based company dealing with sales of second-hand and end-of-life mobile phones. She was working close to 80 hours a week and as a result, did not have enough time to meet other online workers in the locality or socialise with them. We asked all workers in our sample if they know anyone in their locality and if they meet with them regularly. While 
some workers knew other digital workers in their cities, they usually find it hard to socialise with them. One of Mukondi's co-workers on this job contract went to the same university in Nairobi, and they never met. Instead, workers tend to utilise whatever time they have to find new work, instead of trying to establish connections with workers either through the internet or locally. As another Kenyan worker, Isa, who does search engine optimisation, said: 'when you're busy you have no time to go look for another guy'. Since there is intense competition between workers on a global scale on these outsourcing platforms, it is understandable that workers will want to prioritise continuously looking for work instead of developing capacities for collective organisation. The extreme physical separation of digital workers also makes any collective organisation or physical co-presence unlikely. We found a few local networks of platform workers in Ghana, Nigeria and Kenya, where multiple small groups of workers (2-3 workers in a group) have developed close working collaboration. Workers also develop networks through social media, although the utility of such networks to transform worker power is debatable.

Figure 1 indicates that a range of underlying economic, social, and political factors end up bringing into being particular geographies of work. While work can in theory be done from anywhere, myriad factors end up influencing concentrated economic geographies of jobs. Irrespective of its actual geographies, digital work is sufficiently mobile for workers and clients to feel that the marketplace they are operating in is truly global. The result is that workers can lose a sense of any collective organisation and feel replaceable, while clients exploit this lack of associational power of workers to exert their demands on workers (also see point 5, below). Ben, a virtual assistant in Kenya, explains the feeling of being replaceable. He said, 'basically I can do what I want but there is always that feeling like what happens tomorrow if the company can't afford me, do I have to cut my salary or what 
happens if I wake up in the morning and there is this email from Upwork, contract ended. That's the email I fear the most'.

\section{3) Employers obtain information about workers}

The way platform work is designed and transacted over the Internet reveals stark asymmetries in the ways in which employers and workers obtain information about each other, and what they do with that information. While the bidding process enables labour power to be bought as a commodity in the market, a real sense of this commodification comes from the nature of the digital work and types of job contracts offered on digital platforms. Due to the digitally-intensive nature of work activities traded on these platforms, these work tasks can be broken down into simpler tasks (or 'gigs') which can be completed by individual workers in a matter of minutes or hours from their homes. Since these tasks can finish quickly, they have to repeat the same bidding process in order to secure new jobs (though some experienced and top-rated workers may get repeat clients who offer work to them directly). There are relatively few jobs advertised that allow some form of trust or working relationship to develop between workers and the employers-usually hourly contract jobs such as digital marketing, social media management, and virtual assistant. But even here there is a problem. Some platforms give clients the power to pay workers only if they are satisfied with their work, and as a result, some workers do not get paid even after they submit their work to clients.

This level of fragmentation of work and commoditisation of labour power means the employer-employee relations become contingent (Barker and Christensen, 1998; Barley and Kunda, 2006), and employers are under no obligation to help workers build long-term careers on platforms. The potential for workers to gain experience and build up knowledge 
and skills for future career development is also constrained, meaning less scope for workers to upgrade to high-skilled and high-income jobs on platforms. A data entry worker with no formal education and training is highly unlikely to go on to software development tasks or graphic design. Clients don't usually provide/offer training for their platform workforce to upskill them. $^{6}$

Employers are able to demand any information they want prior to the job offer and workers are obliged to supply that information in a codified and quantified form (ratings, hours worked and wage rates), allowing clients to assess the workers' quality and ability to work. Since only workers bid for jobs posted by employers, they signal (or give information to) employers on platforms about their quality which employers use to screen workers and make an informed decision who to award the contract. Employers, with all the information about bidding workers at their disposal, are able to choose the workers they want to work with, which might be the worker with the lowest hourly rate, or the top-rated worker irrespective of their rate. In other words, clients have the ability to access all the information they need before awarding the job contract to workers, who usually know little about their clients (see point 4, below). The technical infrastructure of the platforms generates and amplifies an information asymmetry between buyers and sellers of labourin order to favour the buyers (see Graham et. al. 2017b for more on this point). One of the most significant tools that employers use to learn about workers is the rating system (Wood et al. 2018b). As one worker, Mukasa, in Uganda, told us, no client is willing to work with new freelancers with no ratings or feedback, making it difficult for newcomers

\footnotetext{
6 This is not to say that opportunities for workers to learn new skills and earn high income from platform jobs are not present at all. But the point is those who succeed in doing so often come from prosperous family backgrounds and with previous training and education. For example, white South Africans are more much more likely to succeed and earn money on platforms than other groups in the country, largely due to their better socio-material conditions. There are 104 workers on Upwork.com in South Africa (on October 25, 2018), who have completed 1000 hours and earned US\$10,000 worth of work and all but seven are white.
} 
to land a job easily on platforms. During a group discussion with five platform workers in Abuja, Nigeria, they told us that they had to spend months searching for their first job due to an initial lack of ratings. Clients sometimes use this power asymmetry to exploit workers, by offering extremely low-paid work in return for good reviews and high ratings. Adele, in South Africa, told us that she did her data entry work for a client at less than one dollar per hour for about a week (usually eight hours a day). She said 'it was quite tough and I'm like okay, but at least he gave me that shot. He gave me that because after he did give you a good review and feedback'. Onochie, a virtual assistant in Nigeria, explained the importance of ratings for his profile and said:

"I will say my secret is, every client that I work with, I try to leave the best type of impression. Even if the job is not great, I can actually offer to give the client a refund. Not that it was my fault that the whole thing went wrong...So, I paid him back and I told please I do not want a review from you. I do not want a [negative] feedback. That is why I decided to give your money back. So, for every client I work with, I try to do the best possible job that I can, so you can give me the best possible feedback."

\section{4) Workers obtain information about employers}

While the information that employers gain about workers can be used as a form of control, some information about clients can also be visible to workers, such as location, whether or not their payment method has been verified, and an overall feedback score from other workers at the time a bid is placed. However, some specific platforms like Freelancer.com do not allow information on clients hiring history such as total money spent on hiring workers, or average hiring rates to be made available at the time of bidding. Such information would be useful to workers during the bidding process. 
As already discussed in point two above, many workers do not know the identity of their clients or even the nature of their business when placing bids for specific jobs. Referring to her client, Adele in South Africa explained: "She said just do the job and then send it to her. I don't know what she is using these for." Similarly, Kobi in Ghana did data entry work for an American client by sorting 5000 questions into different subject categories. He said, "It is like a high school website where students post questions and then they get tutors to answer for them. I think I was doing some kind of back-end work, I'm not too sure what I was doing, but I know that there were questions that people needed to answer." The fact that workers can usually only obtain the type of information employers want to release about themselves makes it hard for these workers to upgrade into new job types.

Workers we spoke to told us that they would often find that the person hiring them on a platform is actually an intermediary working for a client who is located elsewhere (a finding replicated in Graham et al. 2017b). Since digital work can be transferred easily from one location to the other, multiple levels of intermediation can take place, which can effectively obscure knowledge about the source client. This inhibits the ability of workers to take action against their clients in the events of threats of unfair dismissal and non-payment of wages. Since workers and clients are usually separated by large distances and often based in different legal and regulatory landscapes/setting, it is hard for workers to imagine how they would hold clients to account through courts.

Workers are ultimately given just enough information about clients in order to allow transactions to take place. But the fact that workers often cannot see much about the production networks that they are embedded into, or learn much about their clients, limits their bargaining power. For instance, a worker who doesn't even know what industry they 
are working in would have a hard time offering knowledge they learnt on the job to other potential employers.

\section{5) Offers to buy and sell labour transpire}

The four previous characteristics all allow a planetary labour market to be brought into being ${ }^{7}$, supporting offers to buy and sell labour across the world. According to Horton et al. (2016), 90\% of transactions on Upwork.com are across international borders.

The offers that occur in this international market are characterised by a huge power imbalance between workers and clients. The high-level of individualisation and commoditisation of labour power, the planetary scale of the labour supply for the platform work and an intense competition between workers means that workers are both left to fend for themselves and compete against one another. The international nature of the transactions that occur leave many workers with an understanding that local labour regulations are of little use in protecting them against some of the worst problems they experience in the platform economy. Some workers we spoke to in places as varied as Kenya, Uganda, and Nigeria earned \$1 per hour or less for some of their jobs. However, it was generally understood that not only do their clients have no sense of what a local minimum wage is in their jurisdiction, but also that such considerations would be unenforceable due to the contract types and the fact that local regulators would have little power over foreign clients. Not only are wages often bad, but so too are working conditions. Zain in Ghana explained: Yes, there's been days that I've stayed up for two days of no sleep

\footnotetext{
${ }^{7}$ Furthermore, the nature of many digital work platforms, with work done remotely, collaboratively, and in-real time, means that the 'work place' rather than the just the labour market could be considered to be planetary (bearing in mind similar geographic caveats discussed in this paper). This, however, is a topic for another paper.
} 
at all, not even 30 minutes of sleep because there's a project, I have to get it done and the pay is shit, but you have to get it done." Again, the international nature of the market leaves the sorts of relationships that are set up to encourage Zain to work for days without sleep entirely unregulated.

Workers' lack of bargaining power is also exemplified by the fact that clients can decide to end the contract at any time (without payment of wages), if they are not satisfied with the work submitted by workers. This is particularly pronounced for workers doing fixed-rate or "piecework." Several article writers (mostly paid per article) we interviewed reported that they did not get paid for their article after they submitted their work to their employers because the employers did not like it. One platform worker in Ghana, Quinn, (editor, web research and data entry) edited a book for an American client and clocked 40 hours for a total of US\$ 400 but only got paid US\$200 and despite several complaints made to the platform, she was not paid at the time of the interview.

The lack of structural power for platform workers both manifests in, and is manifested through, the inability of workers to collectively bargain. Offers to buy and sell labour happen at the individual level, making it hard or impossible for workers to take advantage of collective bargaining agreements, or use their collective power to withdraw labour. Dabiku in Kenya was of the opinion that collective bargaining through unions is a good idea. But he remarked, "locally it is unfortunate guys do not trust each other that is one thing. So actually, even [setting up] meetings is always a problem." He was also of the view that while unions would be of help for local work, nothing can be done when clients are located in the US or Canada.

As the millions of offers to buy and sell labour transpire on digital labour platforms, the asymmetries of information and pre-existing asymmetries of power are put into practice by 
clients. In other words, while people buy and sell labour in a spatially-unbounded way, there is a scalar mismatch in reach, mobility, and information that severely limits the bargaining power of workers.

\section{Planetary Labour Futures}

Following the call by Strauss (2018: 626) for "sustained critical attention to what is distinctly spatial about the processes that are of interest, how place matters to those processes, and how scale is relationally constructed [...] and experienced in the production of precarious work situations," this article has explored the ways in which inequality is structured into online labour markets when they are scaled up to the planetary level. We have seen, following Fevre (1992), that employers can learn about workers, workers learn about jobs, both parties learn about each other, and transactions take place in ways that seemingly ignore some of the traditional limitations of time and distance. Employers and workers, through the affordances of digital technologies, can seek each out a genuinely worldspanning scale, escaping some of the constraints that previously bound them exclusively to their local labour markets. Most importantly, many previously bounded labour markets were both transactionally and discursively insulated from a global reserve army of labour and the downward pressure on wages and working conditions that it brings about (Huws and Leys, 2003). ${ }^{8}$ A market that is planetary in scale will cease to have any of those brakes on the erosion of working conditions. Yet, while all of these interactions occur between

\footnotetext{
8 This is not to claim that local labour markets ever reach any sort of equilibrium. Indeed, much important scholarship has taken place refuting such ideas and instead arguing that labour markets are locally constituted (Craig et al., 1982; Hanson and Pratt, 1992; Harvey, 1989; Peck, 1989). It is nonetheless clear than many bounded labour markets have been able to avoid an erosion of working conditions through the relative scarcity of labour power and better regulatory frameworks instituted by states.
} 
economic actors in different parts of the world from one another, what we see is not just Hardy's hiring fair scaled-up to a global-level or scaled-down onto the head of a pin. Instead of seeing the space of the labour market through a Euclidean lens in which geography is a pre-existing canvas on which economic relationships can be formed, the spaces of labour markets are instead relational and emergent.

It is this understanding of space that we seek to bring to discussions about digital work. The discussion in this paper should encourage us to move away from thinking about labour markets as bounded spaces that you could draw on a map. In a planetary labour market, everything does not happen everywhere. But, key spatial constraints (e.g. the need for commuting, to leave the house, and to obtain visas and permits) can be circumvented. This forces us not to imagine away the always-existing economic geographies of work, but to ask questions about how they will shape and be shaped by the potentials for planetary-scale interactions.

Thomas Friedman (2005: 110) famously pointed to a globalized world that would allow for "the sharing of knowledge and work - in real time, without regard to geography, distance, or, in the near future, even language." But, as much as some firms and clients might want it to, a planetary market doesn't do away with geography; it rather exists to take advantage of it. Platforms use uneven geographies to facilitate labour arbitrage, cross-border competition, and are able to foster what Peck (2017: 42) refers to as an 'offshore consciousness.' To be clear, references to local labour markets, national labour markets, and planetary labour markets should never be made to ignore the myriad ways that those labour markets are brought into being by multi-scalar exogenous factors which, in turn, lead them to be socially and spatially segmented and fragmented. The spatial and scalar prefixes (urban-, local-, national- etc.) that we add to labour markets instead are intended to signify 
enablers and constraints that serve to cluster coming-togethers of employers and workers within particular economic geographies. These enablers and constraints can be technological barriers (e.g. transportation costs and the availability of broadband), political (e.g. the availability of visas and work permits), social (e.g. availability of skills and language fluencies), economic (e.g. local reserve wages) and spatial (e.g. work and workers that inherently have to be in particular places).

Underlying material economic geographies of workers and clients are therefore never fully transcended, work is never fully commoditised, and there remain national and regional practices and institutions which govern the purchase, sale, and pricing of labor on platforms. But none of those national and regional practices determine the shape of the market as a whole. This is not to say that labour markets in non-digital contexts do not have similar ways of empowering and disempowering different groups. The material architectures, norms, laws, and relationships in traditional labour markets all bring particular power dynamics into being. However, what is different in the digital context is that co-presence and the transitory proximity that platforms bring into being is illusory. While workers can, in theory, connect from anywhere, they lose the ability to control a key part of their agency that they otherwise have in any other context: their control over space, and their ability to bring into being labour geographies that are at least in part on their own terms (see e.g. Herod, 2001). Because employers and workers have significantly different abilities to control space, the planetary labour market is a context that serves to further undermine the structural power of labour vis-à-vis that of capital.

This manifests in six key ways. First, mass global connectivity is bringing onstream a massive oversupply of labour power, mainly from lower-income segments of the world population. There are far fewer digital jobs than there are people able and willing to do them. The 
'elemental rationale' of offshoring has always been to cut and supress costs (Peck 2017: 10), it should therefore come as no surprises that online outsourcing continues the trend. Second, many workers seeking jobs in a planetary labour market are replaceable and interchangeable. This is not just due to the oversupply of labour power, but also to the fact that production networks can be footloose while workers are tethered to place. Third, workers mostly interact as competitors rather than collaborators. For digital workers, this situation arises primarily because there are few physical sites at which to assemble with coworkers and because the highly commodified nature of their jobs can lead to competition on price above all else. Digital platforms deliberately limit the amount of horizontal information that workers can glean about one another, and the distributed nature of work means that workers have few opportunities to engage in collective action afforded by spatial proximity. Fourth, there is a lack of transparency. Although workers can use digital tools to find jobs on the other side of the planet, the networks and platforms used to mediate those jobs can also conceal much about the nature of those activities. In other words, workers often know little about the production networks that they are embedded into and are offered few opportunities to economically upgrade skills or value chain positions. Fifth, there is a relative lack of agency amongst workers to have their voice in, or shape, their labour conditions. The affordances of most types of digital work tend to be closed to workers- in part because workers rarely have any stake or control in the physical or digital means of production in the digital economy. If we extend spatial metaphors to online labour platforms, they are not public markets; they are rather private spaces. Finally, workers tend not to be protected by labour laws. Because the labour market extends well beyond any individual jurisdiction's ability to regulate it, self-regulation tends to be carried 
out by platforms and clients. Labour laws that exist to protect workers are ignored in some cases, sometimes even wilfully.

These issues amplify each other, and all serve to undermine the structural power of workers. And they are all possible because of the specific designs of planetary labour markets that use space against workers. The issues outlined in this paper paint a picture of a grim future for the balance of power between labour and capital that is likely unsatisfactory to anyone who doesn't run an outsourcing company. But what can be done if we want to envision and see more equitable outcomes? The solution cannot simply be to turn our backs on innovations in information and communication technologies. We can likely never go back to a world only characterised by local labour markets.

Despite the concerns presented here ${ }^{9}$, the digitally-mediated relationships presented in this article are far from inevitable. There are two primary reasons why we believe this to be the case. First, all of the digital and virtual infrastructure deployed to bring a planetary labour market into being ultimately depends on material infrastructures, organisations grounded in physical places, and real-world regulation. Current configurations of infrastructure and regulation are thus far from inevitable. Interventions such as platform cooperatives, attempts at cross-border regulation, and horizontal organising amongst workers are more effectively covered elsewhere (Graham and Anwar, 2018; Graham and Woodcock, 2018; Irani and Silberman, 2013; Wood et al., 2018a), but the simple point here is that by understanding the spatialities and temporalities of contemporary labour markets, we can

\footnotetext{
${ }^{9}$ Here it is worth bearing in mind that the planetary scale of the market allows many workers to access jobs and income that they simply would not otherwise have access to. The biggest problem for many potential workers is not that the labour market is full of bad jobs, but rather that they are excluded from those jobs in the first place (as we outline in the section on oversupply). However, the fact that bad jobs are better than no jobs should not stop us from interrogating the conditions that bring these jobs into being.
} 
better shape them. We can no longer think about labour markets for digital work as being simple shapes on a map.

Second, the ways in which technologies are deployed to produce specific time-spaces and not others do not dictate how we necessarily use, produce, or jump-over geographies. Indeed, code and algorithms co-produce spaces that are often malleable and hackable (Zook and Graham, 2018). Workers and their advocates have thus far certainly found ways of using technological infrastructures in unintended ways that work in their favour (Wood et. al. 2018a), and we will need more of this if workers are to exert any significant amount of agency in the labour process. But to build or perform alternatives, we again need to base our efforts on realistic understandings of the relationships between economic actors, technologies, and the spaces they bring into being. In Hardy's hiring fair, we wouldn't expect workers to be able to collectively bargain or form a picket if they misread the opportunities and constraints provided by their spatial proximities.

This paper ultimately builds on Doreen Massey's (1994) 'global sense of place' - a sense of how distant people, places, and processes are always inherently enrolled into any local relationships. We do that by showing that we can use five characteristics of labour markets to think about how online labour platforms create labour markets that are planetary in scope. It has also shown some of the ways in which constructing a planetary labour market changes the balance of power between labour and capital. We have demonstrated not that geography has been eliminated, nor that places have been made irrelevant. No virtual space has been created allowing employers and workers to co-exist beyond the confines of the physical realm. Rather what has happened is that digital technologies have been deployed in order to bring into being a labour market that can operate at a planetary scale, and has particular affordances and limitations that rarely bolster both the structural and 
associational power of workers. Digital technologies that underpin online labour markets

help clients operate unboundedly and trans-spatially, and allow them to reconfigure the

geography of their production networks for almost zero cost. Workers meanwhile can sell

their labour power globally, but still are tethered to the locales in which they go to bed

every night.

\section{References}

Kathleen Barker and Kathleen Christensen, 1998. "Contingent work: American employment relations in transition". Ithaca: ILR Press.

Stephen Barley and Gideon Kunda, 2006. "Gurus, hired guns, and warm bodies: Itinerant experts in a knowledge economy." Princeton: Princeton University Press.

Edna Bonacich, 1972. "A Theory of Ethnic Antagonism: The Split Labor Market". American Sociological Review, Vol. 37, pp. 547-559.

Benjamin Bratton, 2016. "The Stack: On Software and Sovereignty". MIT Press, Cambridge MA.

Emily Clark Brown, 1970. "Continuity and change in the Soviet labor market". Ind. Labor Relat. Rev. Vol. 23, pp. 171-90.

Antonio Casilli and Julian Posada, 2019, "The Platformization Of Labor and Society," in: Graham, M., Dutton, W. (Eds.), Society and the Internet, How Networks of Information and Communication Are Changing Our Lives. 2nd Ed. Oxford: Oxford University Press.

Christian Craig, Jill Rubery, Roger Tarling and Frank Wilkinson, 1982. "Labour Market Structure, Industrial Organisation and Low Pay". Cambridge, New York: Cambridge University Press.

Peter Doeringer and Michael Piore, 1985. "Internal Labor Markets and Manpower Analysis." M.E. Sharpe.

R. Fevre, 1992. "The Sociology of Labour Markets". Harvester Wheatsheaf.

T. Friedman, 2005. "The World is Flat". New York, Farrar, Straus and Giroux.

M. Graham and M. A. Anwar, 2018. "Two Models for a Fairer Sharing Economy", in: Davidson, N., Finck, M., Infranca, J. (Eds.), Cambridge Handbook on Law and Regulation of the Sharing Economy. Cambridge, Cambridge University Press.

M. Graham, V. Lehdonvirta, A. Wood, H. Barnard, I. Hjorth and Simon, 2017a. "The Risks and Rewards of Online Gig Work At the Global Margins". Oxford Internet Institute, University of Oxford.

Graham, M., Hjorth, I., Lehdonvirta, V. 2017b. Digital labour and development: impacts of global digital labour platforms and the gig economy on worker livelihoods. Transfer: European Review of Labour and Research. 23 (2) 135-162.

Mark Graham and Jamie Woodcock, 2018. "Towards a Fairer Platform Economy: Introducing the Fairwork Foundation”. Alternate Routes: A Journal of Critical Social Research Vol. 29.

Stephen Graham, 1998. "The end of geography or the explosion of place? Conceptualizing space, place and information technology." Prog Hum Geogr Vol. 22, pp. 165-185.

Susan Hanson and Geraldine Pratt, 1992. "Dynamic Dependencies: A Geographic Investigation of Local Labor Markets." Economic Geography Vol. 68, pp. 373-405. 
D. Harvey, 2011. "The Enigma of Capital and the crises of capitalism." London: Profile Books.

David Harvey, 2001. “Globalization and the 'spatial Fix”. Geographische Revue Vol. 2, pp. 23-30.

D. Harvey, 1991. "The Condition of Postmodernity: An Enquiry into the Origins of Cultural Change”. Oxford, Cambridge Mass: Wiley-Blackwell.

D. Harvey, 1989. "The Urban Experience." Baltimore: Johns Hopkins University Press.

R. Heeks, 2017. Digital Economy and Digital Labour Terminology: Making Sense of the "Gig Economy”, “Online Labour”, "Crowd Work”, "Microwork”, "Platform Labour”, Etc. Centre for Development Informatics.

A. Herod, 2001. "Labor Geographies: Workers and the Landscapes of Capitalism." New York: Guilford Press.

John Horton William R. Kerr Christopher Stanton, 2016, "Digital labor markets and global talent flows" Working Paper No. 23398, National Bureau Of Economic Research, http://www.nber.org/papers/w23398.

R. Hudson, 2001. "Producing Places”. New York: Guilford Publications.

E.S. Hunt, 2010. "The Medieval Super-Companies: A Study of the Peruzzi Company of Florence." Cambridge: Cambridge University Press.

Ursula Huws, and Colin Leys, 2003. "The Making of a Cybertariat: Virtual Work in a Real World." New York: Monthly Review Press.

L. Irani and S. Silberman, 2013. "Turkopticon: Interrupting Worker Invisibility in Amazon Mechanical Turk, in: Proceedings of the SIGCHI Conference on Human Factors in Computing Systems, CHI '13. ACM, New York, NY, USA, pp. 611-620.

Andrew Jones, 2008. "The rise of global work." Transactions of the Institute of British Geographers Vol. 33, pp. 12-26.

Arne Kalleberg and Aage Sorensen, 1979. "The Sociology of Labor Markets.” Annual Review of Sociology Vol. 5, pp. 351-379.

S. C. Kuek, C. Paradi-Guilford, T. Fayomi, S. Imaizumi and P. Ipeirotis, P. 2015. "The global opportunity in online outsourcing”. World Bank, Washington D.C.

K. Marx, 1973. "Grundrisse: Foundations of the Critique of Political Economy." London: Penguin Classics.

D. Massey, 1994. "Space, Place, and Gender." Minnesota, University of Minnesota Press.

D. Massey, 1993. "Power Geometry and a Progressive Sense of Place", in: Bird, J., Curtis, B., Putnam, T., Tickner, L. (Eds.), Mapping the Futures: Local Cultures, Global Change. London, New York : Routledge.

D. Massey, 2005. "For space". London, SAGE Publications.

S. Ojanperä and M. Graham (2018) "Mapping the availability of online workers". At, https://geonet.oii.ox.ac.uk/blog/mapping-the-availability-of-online-workers/, accessed on 27 October, 2018.

J. Peck, 2017, “Offshore: exploring the worlds of global outsourcing”, Oxford, Oxford University Press.

J. Peck, 1996. “Work-place: The Social Regulation of Labor Markets". New York: Guilford Press.

Jamie Peck, 1989. "Reconceptualizing the local labour market: space, segmentation and the state". Progress in Human Geography Vol. 13, pp. 42-61.

Michael Reich, David Gordon and Richard Edwards, 1973. A Theory of Labor Market Segmentation. The American Economic Review Vol. 63, pp. 359-365.

B. Silver, 2003. "Forces of labor : workers' movements and globalization since 1870." Cambridge: Cambridge University Press.

N. Srnicek, 2016. "Platform Capitalism”. Cambridge Malden, MA: Polity Press. 
Kendra Strauss, 2018. "Labour geography 1: Towards a geography of precarity?" Progress in Human Geography Vol. 42, pp. 622-630.

Alex Wood, Villi Lehdonvirta, and Mark Graham, 2018a. "Workers of the Internet unite? Online freelancer organisation among remote gig economy workers in six Asian and African countries." New Technology, Work and Employment Vol. 33, pp. 95-112.

Wood, A., Graham, M., Lehdonvirta, A., and Hjorth, I. 2018b. Good Gig, Bad Big: Autonomy and Algorithmic Control in the Global Gig Economy. Work, Employment and Society. https://doi.org/10.1177/0950017018785616

Matthew Zook and Mark Graham, 2018. "Hacking Code/Space: Confounding the Code of Global Capitalism." Transactions of the Institute of British Geographers Vol. 43, pp. 390-404. 